\title{
Design and Development of Solar Charging System for Electric Vehicles: An Initiative to Achieve Green Campus
}

\author{
Gnanasekaran Sasikumar*† and A. Sivasangari** \\ *Department of Mechanical Engineering, GMR Institute of Technology, Srikakulam-532127, Andhra Pradesh, India \\ **Department of Electronics and Communication Engineering, GMR Institute of Technology, Srikakulam-532127, \\ Andhra Pradesh, India \\ †Corresponding author: Gnanasekaran Sasikumar; sasikumar.g@gmrit.edu.in
}

Nat. Env. \& Poll. Tech.

Website: www.neptjournal.com

Received: $18-05-2020$

Revised: 11-06-2020

Accepted: $13-07-2020$

Key Words:

Green energy

Renewable energy

Solar photovoltaic

Solar vehicle

\begin{abstract}
Renewable energy is a kind of energy that is obtained through different resources such as sunlight, wind energy, tides, geothermal etc. It provides clean energy that comes from natural sources which can be replenished continuously. The utilization of more amount of renewable energy will lower the prices of and demand for fossil fuels. Solar photovoltaic energy is predominantly used for many applications like heating, cooking and power generation. Recent inventions helped in developing vehicles that are driven by solar energy. In this paper, the design and development of a solar charging system for electric vehicles using a charge controller is discussed. Implementation of the proposed system will reduce the electricity cost and charging and discharging losses. Also, the proposed solar charging system will be one of the initiatives taken to achieve Green campus. This paper will demonstrate the system design and performance analysis of a solar-charged electrical vehicle system.
\end{abstract}

\section{INTRODUCTION}

The demand for energy is increasing due to the increase in population and the economic conditions of many countries. Recent research works reported that fossil fuels have limitations such as global warming, limited resources and economical issues. The energy crisis is expected in the near future and the utilization of renewable energy is to be explored to the maximum possible extent to overcome the problems that arise out from fossil fuels. Many researchers suggested the use of renewable energies considering many environmental aspects. Renewable energy such as solar energy can be an effective alternative in terms of its availability, cost-effectiveness and environmental friendliness.

\section{ELECTRIC VEHICLE CHARGING SYSTEM}

The combination of electric vehicles (EVs) and photovoltaic generation (PV) was developed and their performance was studied. In the model, a linear optimization model is used to assess its impact on the energy system (Fattori et al. 2014). The design criteria, setting up, control strategies and experimental tests applicable for a power configuration of DC micro-grid for rapid charging of full electric and plugin hybrid vehicles. The proposed charging architecture is derived from an analysis comparing the main characteristics of well-known architectures. The study of the proposed power conversion architecture is focused on the evaluation of charging/discharging power, efficiency, energy flux management and its impact on the main grid. In addition, proper control strategies are evaluated and implemented, allowing the proposed architecture to follow the required operations. The operation of electric vehicles using renewable energy systems is an environmentally friendly technology (Capasso et al. 2015). A smart charging station was developed for Plug-in Hybrid Electric Vehicles (PHEVs) based on DC link voltage sensing (Goli et al. 2014).

A specific combination of electric vehicles with photovoltaic systems was reported which are mainly used for home to work or home to education transports operated from a grid connected photovoltaic system. For this application, two strategies for the smart charging of electric scooters are investigated. The study also concluded that this application permits operation of electric scooters against fuel scooters with no higher costs and with less $\mathrm{CO}_{2}$ emissions (Mesentean et al. 2010). An electric circuit-based battery and a capacity fade model was developed suitable for electric vehicles (EVs) in vehicle-to-grid applications. A control algorithm was developed for the battery to compute the processed energy, charge or discharge rate, and state of charge limits of the battery. The obtained battery characteristics were in close agreement with the measured characteristics (Thirugnanam et al. 2014). 


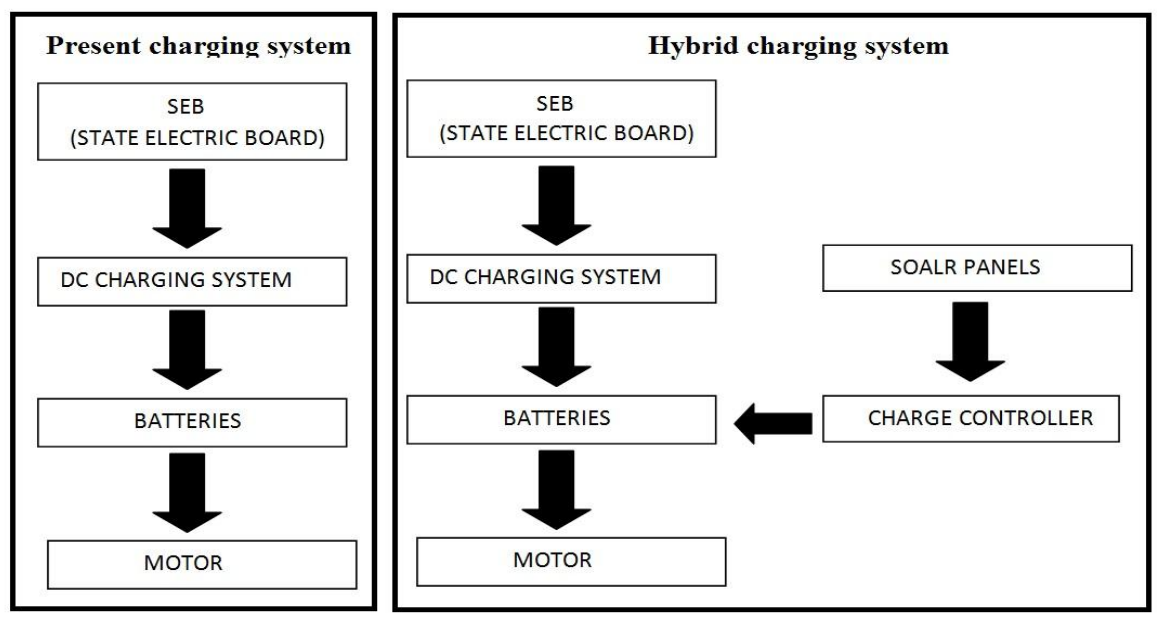

Fig. 1: Vehicle charging system.

A novel bi-directional battery charger for PHEV/EV with a photovoltaic generation system was proposed and the operation algorithm of the battery charger system was studied (Choe et al. 2010). The Charging Stations (CSS) of Electric Vehicles (EVs) and their coordination at the substation level were presented by Fuzzy Logic Controllers (FLCs) at the substation and the CS level (Singh et al. 2013). The design of a power-electronic-assisted On-circuit tap changer (OLTC) was proposed for grid voltage regulation (Chandra Mouli et al. 2015).

Electric vehicles require electricity for charging the batteries. This involves the increment of operational costs hence replacing this system with solar energy would nullify the high operational costs. So in order to convert the normal electric vehicles into hybrid electric vehicles, some solar panels and a specialised charge controller is necessary. Solar panels help in trapping and converting the solar energy into electrical energy while the charge controller regulates and selects the source for charging as shown in Fig. 1.

Solar charging for electrical vehicles is a basic and viable application of using solar energy to achieve sustainable energy development. The solar charging is based on the utilization of solar PV panels for converting solar energy to $\mathrm{DC}$ voltage. The DC voltage can be stored in the battery bank by a charge controller. An inverter is employed to convert the DC voltage from the battery bank to 110 volt $\mathrm{AC}$ at $60 \mathrm{~Hz}$ frequency that is identical to the power from the electric outlet. This paper will address the fundamental concepts of designing and developing solar PV systems for charging electrical vehicles for an educational institute.

\section{COMPONENTS OF VEHICLE CHARGING SYSTEM}

For successful implementation of the project, the following are the main components required:

1. Electric vehicle

2. Solar Photo-Voltaic module

3. Charge controllers

\section{Electric Vehicle}

The following section explains the requirements of the vehicle which will be charged by solar energy. The Graphical representation of electric vehicle is shown in Fig. 2.

Design calculations: Power (Watts) $=$ Weight of vehicle

$(\mathrm{kg}) \times \mathrm{g}\left(\mathrm{m} / \mathrm{s}^{\wedge} 2\right) \times \max$. speed $(\mathrm{m} / \mathrm{s}) \times \operatorname{gradient}(\%)$

$$
\mathrm{P}=175 \times 9.81 \times 5.5 \times 3 \%=282.9 \text { Watts }
$$

Hence, the Motor specification selected for this electrical vehicle is 300 Watts, $48 \mathrm{~V}$ BLDC motor.

$$
\text { Load current }=300 \mathrm{~W} / 48 \mathrm{~V}=6.25 \mathrm{~A}
$$

The vehicle is used for 2 hours/day and assuming $20 \%$ losses,

So, load current per day $=2.0 \times 6.25 \times 1.2=18 \mathrm{AH} /$ day

Energy required for $300 \mathrm{~W}$ motor is $6.25 \times 18=864$ W/day

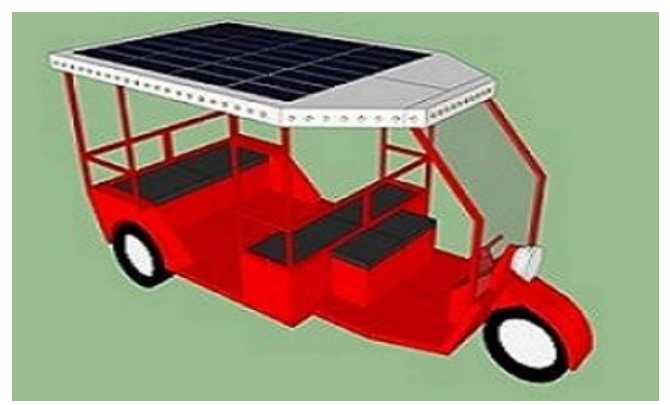

Fig. 2: Graphical representation of the electric vehicle. 
Table 1: Specifications of available electric vehicle

\begin{tabular}{|ll|}
\hline Parameter & Rating \\
\hline No. of batteries & 4 \\
Rating of the batteries & $12 \mathrm{~V}, 150 \mathrm{AH}$ \\
Charging voltage & $48 \mathrm{~V}$ \\
Area on top (in ft) & $5{ }^{\prime 2}(\mathrm{~L}) \cdot 3{ }^{\prime \prime}(\mathrm{B})$ \\
Seating capacity & $4+1$ \\
Motor specifications & $48 \mathrm{~V}, 300 \mathrm{~W}$, BLDC motor \\
\hline
\end{tabular}

Therefore $48 \mathrm{~V}, 18 \mathrm{AH} /$ day is required for the system which can be supplied by four $12 \mathrm{~V}$ batteries of $150 \mathrm{AH}$. Based on the above calculations, the specifications of the electrical vehicle are listed in Table 1.

\section{Solar PV Module}

PV modules consist of many PV cell circuits, normally in series, sealed in an environmentally protective laminate and are the fundamental building block of PV systems. The PV cells convert sunlight into DC current electricity. The specifications of solar PV panel required for the project is depicted in Table 2.

\section{Charge Controller}

The charge controller is used to receive and regulate the input voltage from PV power source and stores the energy by charging the battery bank. The charge controller circuit diagram connecting with other components such as solar panels and battery is shown in Fig. 3.

The complete assembly of the solar-powered vehicle system is shown in Fig. 4.

\section{COST ESTIMATION FOR SOLAR CHARGING INSTALLATION}
Cost of Solar PV panels
Rs. 12000
Charge controller
: Rs.1500
Cables, clamps and other
accessories
: Rs. 1500

Table 2: Specifications of solar PV module.

\begin{tabular}{|ll|}
\hline Parameter & Rating \\
\hline Operating Voltage & $12 \mathrm{~V}$ \\
Maximum Power (Pmax) & $75 \mathrm{~W}$ \\
Open Circuit Voltage (Voc) & $22.72 \mathrm{~V}$ \\
Short Circuit Current (Isc) & $4.32 \mathrm{~A}$ \\
Maximum Power Voltage (Vmp) & $19.04 \mathrm{~V}$ \\
Maximum Power Current (Imp) & $3.89 \mathrm{~A}$ \\
Maximum System Voltage & $1000 \mathrm{~V}$ \\
\hline
\end{tabular}

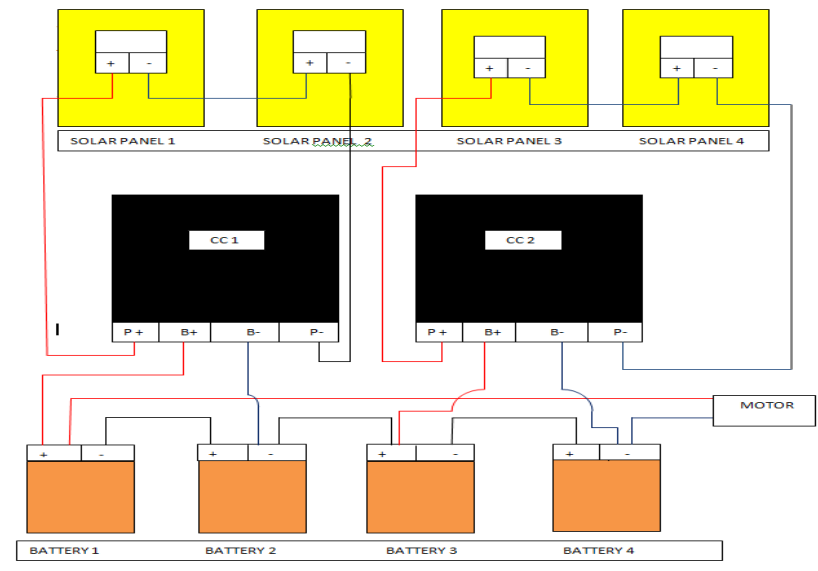

Fig. 3: Charge controller circuit diagram.

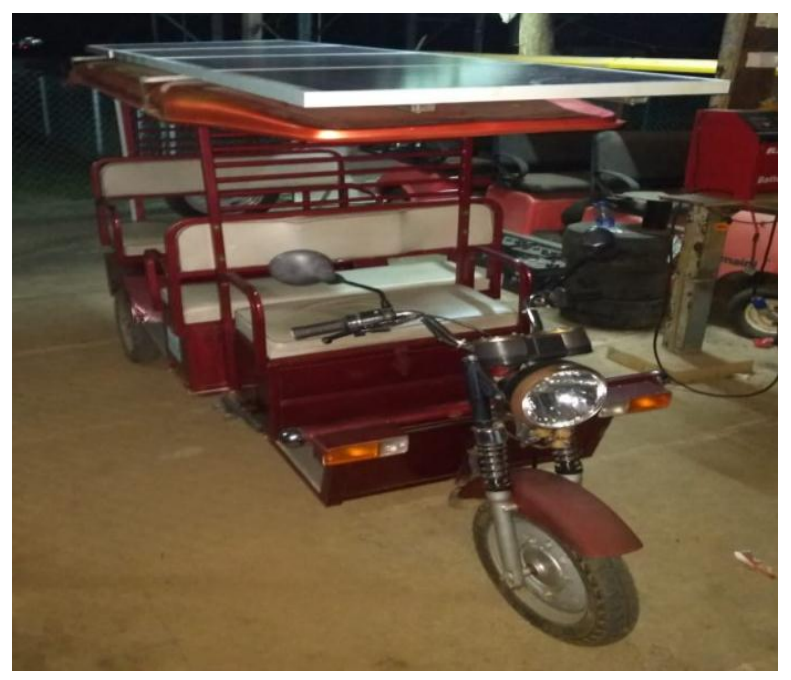

Fig. 4: Assembly of solar powered vehicle system.
Generation/day
$: 1.5$ units/day
Generation/year
: 547.5 units/year
Charge/unit
: Rs.7.8/unit
Revenue /year
Payback period
: Rs.4270/year
$: 3.5$ years

\section{COMPARISON OF PROPOSED SOLAR AND EXISTING ELECTRICAL CHARGING SYSTEM}

The cost and other operating parameters related to the proposed solar and existing electrical charging system are shown in Table 3. From Table 3, it is understood that the proposed solar charging system is superior in terms of functional and economical considerations. 
Table 3: Comparison of the proposed solar and existing electrical charging system.

\begin{tabular}{|lll|}
\hline Parameters & $\begin{array}{l}\text { Proposed Solar } \\
\text { charging system }\end{array}$ & $\begin{array}{l}\text { Existing Electrical } \\
\text { charging system }\end{array}$ \\
\hline Maximum speed & $20 \mathrm{Km}$ per Hour & $20 \mathrm{Km}$ per Hour \\
Initial cost (Rs) & 15000 & 10000 \\
$\begin{array}{l}\text { Distance covered after } \\
100 \% \text { charging }\end{array}$ & $42-45 \mathrm{Km}$ & $40 \mathrm{Km}$ \\
$\begin{array}{l}\text { Charging time (Hours) } \\
\text { Operating cost (Rs) }\end{array}$ & 8 & 7 to 8 \\
$\begin{array}{l}\text { System operation } \\
\text { guarantee (Years) }\end{array}$ & 25 & 7.5 per unit \\
\hline
\end{tabular}

\section{CONCLUSION AND FUTURE SCOPE}

The development of the Solar Charging system for electrical vehicles project comprised of various disciplines like electrical, electronics, and mechanical engineering technologies. This paper attempted to provide a framework for the design and development of a solar charging system which would provide an opportunity for the students to learn the theoretical aspects and hands-on experience of utilizing solar energy. The proposed solar charging system will be one of the initiatives taken to achieve a Green campus. The design considerations and calculation for various components are presented in detail. The economic analysis of the proposed system reveals that the payback period of the project is 3.5 years. It is clearly evident from Table 3 that the proposed solar-based vehicle charging system is better than the existing electrical charging system both in terms of operation and economical aspects. Researchers work on this project get a basic idea of the design and building of Solar PV systems for several useful applications such as electrical vehicle system.

Based on the proposed project, many new works will be developed to design an efficient system for further applications. The performance analysis of the solar-charged vehicle system will be carried out to enhance the efficiency of the pilot project. As a measure to reduce the carbon footprint to achieve energy sustainability, this project will be further enhanced. In addition to this solar charging system, an effort will be made to operate all battery-operated vehicles available on the campus to utilize solar energy by establishing more charging stations. This initiative will encourage energy sustainability on campus and inspire the various stakeholders such as students, faculty and staff to use public transportation and electric vehicles that are charged by solar energy.

\section{ACKNOWLEDGEMENT}

The authors are grateful to their management for allowing them to do this research and thankful to the anonymous referees for their valuable suggestions to enhance the features of the content.

\section{REFERENCES}

Capasso, C. and Veneri O. 2015. Experimental study of a DC charging station for full electric and plug in hybrid vehicles. J. Applied Energy, 152: 131-42.

Chandra Mouli, G.R., Bauer, P. and Zeman, M. 2016. System design for a solar powered electric vehicle charging station for workplaces. J. Applied Energy, 168(15): 434-443. doi.org/10.1016/j.apenergy.2016.01.110.

Choe, G.Y., Kim, J.S. and Lee, B.K. 2010. A Bi-directional battery charger for electric vehicles using photovoltaic PCS systems. In: IEEE Vehicle Power Propuls Conf., IEEE, pp. 1-6.

Fattori, F., Anglani N. and Muliere G. 2014. Combining photovoltaic energy with electric vehicles, smart charging and vehicle-to-grid. J. Solar Energy, 110: 438-51.

Goli, P. and Shireen, W. 2014. PV powered smart charging station for PHEVs. J. Renewable Energy, 66: 280-7.

Mesentean, S., Feucht, W., Mittnacht, A. and Frank, H. 2011. Scheduling methods for smart charging of electric bikes from a grid-connected photovoltaic-system. In: UKSim $5^{\text {th }}$ Eur Symp Computer Modeling Simulation, IEEE; p. 299-304.

Singh, M., Thirugnanam, K., Kumar, P. and Kar, I. 2015. Real-time coordination of electric vehicles to support the grid at the distribution substation level. J. IEEE Syst., 9: 1000-10. doi.org/10.1109/ JSYST.2013.2280821.

Thirugnanam, K., Ezhil Reena, JTP., Singh, M. and Kumar, P. 2014. Mathematical modelling of Li-ion battery using genetic algorithm approach for V2G applications. IEEE Trans. Energy Convers., 29: $332-43$. 